\title{
Effective Minority Participation as a Balancing Act: What Role for the OSCE High Commissioner on National Minorities?
}

\author{
Gaetano Pentassuglia"
}

\section{Abstract}

What is the role of the High Commissioner on National Minorities (HCNM) in the context of the political participation of national minorities in their countries? Using the Lund Recommendations and other international instruments as a framework of analysis, this piece seeks to answer this question by offering reflections on selected dimensions of minority participation, including political parties, special measures, consultative bodies, and self-governance, against the broader, oft-cited notions of integration and separation. It points to areas where some degree of standard-setting improvement and clarification under the auspices of the HCNM would be desirable, particularly in the context of the Lund Recommendations, and closes with recommendations for future HCNM activity.

Keywords

Political participation, integration, separation, HCNM, international law

To cite this publication: Gaetano Pentassuglia, Effective Minority Participation as a Balancing Act: What Role for the OSCE High Commissioner on National Minorities?, IFSH (ed.), OSCE Insights 6/2021 (Baden-Baden: Nomos, 2022), https://doi.org/10.5771/9783748911456-06

Introduction: the HCNM's conflict prevention approach to integration and separation

The OSCE High Commissioner on National Minorities (HCNM) was established in 1992 as an instrument of con-

* Gaetano Pentassuglia

Professor of International Law

School of Law

Liverpool John Moores University

Honorary Senior Fellow

University of Liverpool

g.pentassuglia@ljmu.ac.uk. flict prevention designed to generate "early warning" and "early action" on highly sensitive minority issues. ${ }^{1}$ The HCNM has frequently emphasized the importance of "integration", as opposed to "separation", as a vital ingredient in any form of durable minority protection within the state. $^{2}$

The "integration versus separation" narrative is not unknown to other international structures engaged in activities related to group accommodation, particularly those that seek to capture the relevant groups' own distinctive interests and aspirations (e.g. non-discrimination and 
independence). The HCNM's approach to integration and separation is more specific than the approaches taken by other structures, however. Its focus is on integration as a necessary element of social cohesion in diversity management, whereas it views separation in terms of the recognition of specific rights in isolation from a broader, nation-wide sense of belonging and the rights of others. A useful example is language rights protection. It is an HCNM mantra that the right to use and learn one's own mother tongue in educational institutions and/or the right to speak one's own language in (local) public administration, both of which are typically demanded by national minorities, cannot be taken in isolation from measures to teach and learn the official state language for broadly similar purposes. ${ }^{3}$ The approach to minority issues taken in the Baltic States, Georgia, Kazakhstan, and Kyrgyzstan, for example, which have all relied on HCNM assistance in the development of multilingual policies and inter-ethnic dialogue, clearly point in this direction. This is also in line with international standards. ${ }^{4}$

The "integration of diversity", as it has come to be known in HCNM parlance, thus speaks to both the legitimacy and the constraints of protecting national minorities. The interplay of integration and participation best illustrates the balancing act implied by this dynamic. The right to be involved in decision-making processes of relevance to the group, and indeed in public life more broadly, is a constant feature of international norms, both global and regional, applicable to various substate groups. Participation rights can have political, socio-economic, and cultural ramifications, although the integrationist gist of such rights lies in the opportunity for group representatives to have an "effective" say in decision-making, or at least in ensuring that group members have access to a range of public policies.

The Lund Recommendations on the Effective Participation of National Minorities in Public Life ("The Lund Recommendations"), 5 launched by the HCNM in 1999, focus on the political dimension of minority participation by reaffirming the need for a democratic and pluralistic framework that integrates group diversity into society, working against monolithic and exclusivist views of national identity while simultaneously qualifying the scope of that participation in accordance with human rights standards.

Using the Lund Recommendations and other international instruments as a framework of analysis, ${ }^{6}$ this paper will discuss selected HCNM-related dimensions of minority political participation, including political parties, special measures, consultative bodies, and self-governance, against the broader notions of integration and separation. The following section will point to areas where some degree of standard-setting improvement or clarification under the auspices of the HCNM would be desirable, particularly in the context of the Lund Recommendations. These include the role of mainstream parties, the fine-tuning of certain complex "special" measures in electoral processes, the type and depth of pluralism secured by consultative bodies, and the link between self-governance, integra- 
tion, and de-securitization, especially in cross-border regions. A brief set of recommendations will be offered in the concluding section, with a focus on future HCNM activity.

\section{Exploring dimensions of HCNM activities in light of the Lund Recommendations and other international standards}

\section{Political parties}

While some OSCE participating States (including Bulgaria, Russia, and Turkey) have explicitly banned ethnic and prominority parties, the HCNM has been flexible by recognizing both mainstream parties and national and regional minority parties and movements as legitimate channels of political participation for national minorities, and thus as legitimate tools of integration into the nation-wide context of public affairs, representation, and participation in decision-making.

The Lund Recommendations openly endorse this duality, as do the Advisory Committee's Thematic Commentary under the Framework Convention for the Protection of National Minorities ${ }^{7}$ and the European Court of Human Rights (whether explicitly or implicitly). However, the dividing line between integration and separation in the context of party politics requires a proper understanding of its multiple legal and policy ramifications.

Four aspects are worth noting in this regard. First, where they exist, minority parties cannot be treated as a matter of national security unless their activities provide strong evidence to the contrary (think of the string of cases against Turkey before the European Court of $\mathrm{Hu}$ man Rights). This also means that legislative bans on ethnic parties and political movements are in breach of freedom of association under international human rights law unless they target groups with proven violent and anti-democratic agendas.

Second, while minority involvement in mainstream parties is generally welcomed and even encouraged, there are no clear parameters for measuring it. Despite general entitlements such as the right to participate in the conduct of public affairs in Article 25 of the International Covenant on Civil and Political Rights ${ }^{8}$ - including active and passive voting rights, as well as wider notions of internal self-determination - minority parties may prove to be, as the Lund Recommendations put it, "the only hope for effective representation of specific interests, and thus, for effective participation". 9 The Framework Convention's Advisory Committee acknowledges that mainstream parties may not suffice for the effective representation of minority interests, ${ }^{10}$ implying the need for both mainstream and minority parties to remain available. However, international minority standards, including the Lund Recommendations, do not provide clear guidance on the incorporation of minority concerns into mainstream parties that can meet the test of effective participation, although there is significantly more detail at the OSCE and the Council of 
Europe level ${ }^{11}$ of the wider electoral process affecting national minorities.

Third, mainstream parties themselves need to strike a balance between "majority" and "minority" concerns. Mainstream party agendas are usually built around issues that, though potentially cross-cutting, speak primarily to majority priorities. Tellingly, the Framework Convention's Thematic Commentary singles out the candidate selection process as being key to any future pro-minority agenda within mainstream parties. ${ }^{12}$ This is a challenge that replicates the integrative approach to minority issues within the wider society. Fourth, while the broad incorporation of minority issues can be achieved through mainstream parties in traditional liberal democracies, this is more problematic in certain OSCE regions, for example in parts of Central Asia, where ethnicity is often a well-entrenched identity marker in party politics and public life more broadly.

\section{Special measures}

A range of specific measures designed, directly or indirectly, to benefit national minorities in the political process are generally referred to as "special arrangements", or more commonly, "special measures". They range from formal and informal policies focused on securing a more inclusive electoral process - such as the general design of electoral districts, the availability of electoral materials in majority and minority languages, the permissibility of minority languages in electoral campaigning, and even the general structure of electoral laws affecting voting eligibility (language, citizenship, etc.) - to measures that specifically target the group concerned. The latter may include dual voting or reserved seats in elected bodies (parliament, regional assemblies, etc.). The HCNM and other bodies have discussed and supported these measures in various country contexts and to varying degrees. ${ }^{13}$

The first set of measures serves to secure, mainly indirectly, the minimum preliminary conditions that must exist if minorities are to benefit from country-wide processes that would otherwise benefit the majority alone, for example lowering electoral thresholds for party representation and providing bilingual national electoral campaign materials in regions populated by minorities (see, for example, the case of pro-Kurdish parties in Turkey). The same applies to securing greater representation in the judiciary and the civil service. ${ }^{14}$ Here, integration is essentially aimed at the institutional articulation and fair representation of societal diversity.

The second set of measures, while still linked to these broad objectives, identifies areas of separation that are considered necessary for protecting the ability of minority groups to advance their own distinctive interests. Some of these measures have proved problematic, however. For example, the dual voting system applied to certain long-established minorities in Slovenia, whereby minority members are allowed to vote both for general party lists and, separately, for their own minority representatives at the national or local level, has raised issues of com- 
patibility with the principle of equal voting rights. In 1998, the Slovenian Constitutional Court dismissed claims of unconstitutionality by arguing that the system corrects substantive inequalities between ethnic Slovenes and the groups concerned. While the HCNM was sympathetic towards the policy, at least from a conflict prevention perspective, ${ }^{15}$ the Council of Europe's Venice Commission narrowly construed dual voting as a purely exceptional and temporary measure, absent less restrictive alternatives. The Lund Recommendations, for their part, list a range of measures in this area but do not elaborate on their scope or limitations.

It is instructive to recall in this context that, under the UN Convention on the Elimination of All Forms of Racial Discrimination, ${ }^{16}$ a clear distinction has been drawn not only between positive obligations stemming from its articles (and by analogy, any human rights/minority rights standards) and "special measures" as temporary affirmative action policies, but also between the latter and permanent rights accrued to minorities and indigenous peoples:

Special measures should not be confused with specific rights pertaining to certain categories of person or community, such as, for example the rights of persons belonging to minorities $[\ldots]$ and the rights of indigenous peoples [...]. State parties should carefully observe distinctions between special measures and permanent human rights in their law and practice.
If a "special" measure is intended to address structural historical inequalities and injustices affecting a minority group one should assume that it won't necessarily be provisional or transitional in nature, although it will remain subject to proportionality review and possible adjustment over time. There may be good alternatives to, say, dual voting (which is used only in Slovenia and for specific groups). In general, however, ambitious (positive) measures such as reserved seats and specific exemptions from electoral thresholds need to be treated as prima facie minority rights protections, the abolishment of which could have potentially serious consequences for minority participation, inter-communal trust, and social cohesion. ${ }^{17}$ In the absence of a clearly better and widely shared policy supported by the group, the focus should be shifted towards fine-tuning and perfecting measures instead of assuming their transient character.

A good example is offered by the current national minority voting systems in OSCE countries such as Hungary and Kazakhstan. Despite their complexity, largely built around reserved seat mechanisms, the Office for Democratic Institutions and Human Rights (ODIHR) has drawn attention to problematic (and potentially reformable) elements of such systems - including the process of candidate nomination for minority lists, the level of choice provided to minority voters, and the lack of a registration system for such voters - rather than their overall legitimacy and durability as minority rights mechanisms. ${ }^{18}$ 


\section{Consultative bodies}

Consultative bodies provide a quintessentially integrative minimum standard of minority participation. Areas of improvement in this domain have been amply documented and continue to be an important part of relevant HCNM good office efforts. These areas include issues related to legal status, decision-making authority, the frequency of consultations, and the financial resources enjoyed by such bodies.

An emerging area of concern is pluralism, which in this context comes in two forms. The first is pluralism within a given group, which is necessary for generating an accurate representation of a diverse range of views among group members. Matters of representativeness and broader legitimacy have been acknowledged in several settings, particularly the Framework Convention's Thematic Commentary and scholarly assessments, although the Lund Recommendations also indicate, more soberly, that "the composition of such bodies should reflect their purpose and contribute to more effective communication and advancement of minority interests." 19 The HCNM rightly focuses on facilitating internal debate by looking, for example, at the extent to which gender can hamper inclusive processes within groups (as in recent discussions around minority women in North Macedonia). International law recognizes minority participation rights in both the external and the internal domain, which means that the state, while recognizing the autonomous associative life of the community, has at least a duty of due diligence to ensure favourable conditions for inclusive conversations within groups and, consequently, the effective participation of all, in line with basic human rights standards.

Internal pluralism does not entail the collapse of the group's perspective and claims into an uncoordinated bundle of merely individual preferences and concerns. Ideally, it involves incorporating a range of views, as they are normally reflected in community practices, into a position that can still be attributed to the group through accountability and democratic standards. Where this is not possible due to internal divisions (as in the case of certain Roma groups in Europe), the main sectors of the community should be given a voice and standing within consultative mechanisms, similarly to what the European Court of Human Rights has recognized in the context of electoral processes and voting rights involving intra-communal matters. ${ }^{20}$ More broadly, human rights judicial and quasi-judicial practice generally points to the broad mandate of group representatives in claim-making or a degree of protected pluralism across group organizations, especially where representatives are appointed by the state rather than the community. ${ }^{21}$

The latter point is related to the second form of pluralism relevant to this context: the type of diversity that prevails when a variety of groups or group representatives take part in meaningful conversations on matters of concern to them. The focus here is on a greater measure of plurality across the spectrum of minority groups within a country rather than plur- 
alism within a given group. As Anton Petrenko Thomsen has observed, a group's willingness (and ability) to engage in effective consultation is just as important as the set of opportunities and means of participation offered by the political and constitutional framework of the state. ${ }^{22}$ It may be useful to recall that, compared to indigenous peoples' national and international pervasive networking and advocacy, self-standing national minority mobilization has been more limited. The Lund Recommendations do not provide specific guidance in this regard, although minimum conditions for enabling effective participation through consultation across a representative range of community sectors can be derived from basic international instruments. The state should not only allow an inclusive set of minority organizations to sit on consultative bodies (endowed with the legal authority they require to achieve meaningful involvement) but also pro-actively encourage and support - through training, rights awareness campaigns, and financial incentives - the participation of smaller minority organizations that do not wish to be integrated into wider umbrella entities representing the main groups in the country.

As one of the most basic metrics for assessing the quality and depth of the integrative and confidence-building approach to minority issues, the composition and functioning of consultative bodies established by national legislation or in response to multilateral and bilateral standards (mainly bilateral treaties in cross-border regions) requires constant vigilance by the HCNM, from a con- flict prevention perspective. In some cases (for example Kazakhstan and Uzbekistan), such mechanisms are still lacking. This is an area where more targeted HCNM activities, particularly around pluralism and standards, would be useful (see the conclusions section below). This is particularly true given the limited scope of the Lund Recommendations, the more detailed formulations of the Framework Convention's Thematic Commentary, and the expectation that minority organizations themselves will engage with public authorities in good faith, as part of a two-way-street process of (participation-based) integration.

\section{Self-governance}

The Lund Recommendations include territorial and non-territorial autonomy arrangements among the ways and means of implementing the right to the effective participation of national minorities in public life. ${ }^{23}$ While the recognition of such self-governance arrangements essentially restates earlier national/constitutional practice across Europe and beyond, hardly any new territorial autonomy arrangements have been made in the OSCE geographical area since the Lund Recommendations were adopted (1999). Moreover, no right to autonomy has emerged (or is likely to emerge) in international law based on the Recommendations and other international standards.

Yet it would be a mistake to dismiss the Lund Recommendations as being of little use. There are several policy reasons for this. First, it would appear that any 
negotiated settlement of the various socalled "frozen conflicts" in the post-Soviet space, including the more recent additions of Crimea and the southern and eastern parts of Ukraine, must incorporate self-governing arrangements, unless different solutions are deemed acceptable by the parties concerned. Monolithic nation-building projects (in Ukraine and elsewhere) are as unhelpful as the instrumental use of minority claims. Second, self-determination within the framework of an existing state (internal self-determination) so candidly advocated by Max van der Stoel, the first ever HCNM, has been increasingly accepted across the international community (not just in Western Europe and North America) as part of international law and can generate a form of self-government that is tailored to the circumstances of the case and in line with human rights standards. Even established autonomy solutions (such as Gagauzia's self-government in Moldova) still require the nurturing of a wider sense of national belonging through appropriate integration policies, as recently advised by the HCNM. ${ }^{24}$ Third, and relatedly, the non-territorial solutions included in the Lund Recommendations are among a set of tools for integrating diversity (such as multilingual/quality education policies) that make autonomy claims a hybrid and dynamic political and legal proposition. Finally, autonomy options continue to be tested on the ground, not only by violent conflicts but also by "kinstate" involvement in certain cross-border regions.

These factors suggest that the Lund Recommendations' approach to self-gov- ernance should be interpreted in light of other HCNM recommendations, most notably the 2012 HCNM Ljubljana Guidelines on Integration of Diverse Societies and the 2008 Bolzano Recommendations on National Minorities in Inter-State Relations. ${ }^{25}$ Whatever graduated levels of political participation are enjoyed by sub-state national groups as part of a nation-wide process of internal selfdetermination, they should not be seen as stepping-stones towards an inflexible end state defined by the group, whether independent sovereignty or a unique, nonnegotiable idea of self-government that prioritizes separation over integration (in the sense of state-wide social cohesion). The Ljubljana Guidelines remind us that:

$[\mathrm{I}] \mathrm{t}$ is essential for societies to find the appropriate balance between the degree of separation that is necessary to the free expression and development of diversity on the one hand and the establishment and strengthening of links between and among the diverse communities of a society as a whole on the other. ${ }^{26}$

Equally, the Bolzano Recommendations point to territorial integrity, good neighbourly relations, respect for human rights - including the principle of non-discrimination - and democratic governance as key pillars of cross-border region policies involving kin-states, irrespective of the institutional outcomes of group accommodation.

The case of the Hungarian minority in Ukraine before and after the 2014 Euromaidan illustrates the relative (and relational) significance of autonomy in the 
context of national minority protection. On the one hand, unfavourable electoral district design, high electoral thresholds for party representation, the ad hoc cooptation of individual minority leaders into mainstream national lists, and the absence, until recently, of a consultative governmental body to address minority concerns have been barriers to effective national minority participation. On the other hand, the dilution of language/education rights at the local level following new legislation in 2017 and 2019 in the fields of education and state language, respectively, limited or no progress in territorial and non-territorial decentralization, and increasing kin-state involvement have contributed to the situation's technical complexity and political sensitivity. ${ }^{27}$

The HCNM has been engaged in discussions on most of these matters, particularly in the context of developing a draft minority law with a view to replacing the 1992 Law on National Minorities. ${ }^{28}$ Proposals and discussions on reforming local authorities across Ukraine could generate opportunities for accommodation based on a combination of stronger language/education rights in areas of traditional Hungarian settlement (to be balanced against teaching and learning the state language) and some form of acceptable institutional self-governance.

The case of Ukraine's Hungarian minority provides a vivid illustration of both the multidimensionality of minority rights protection and the hybrid approach to autonomy in the real world: self-governance raises various issues affecting groups, individuals, and the sta- bility of the state, beyond "territorial rights" per se. In this sense, the Lund Recommendations help to contextualize country situations and, together with other HCNM Recommendations and international standards, provide a democratic framework for addressing them in the face of the instrumentalization of minority issues by self-serving national governments. Indeed, kin-state involvement de facto challenges the central government's engagement with autonomy claims insofar as they are perceived as a threat to social cohesion. By working towards desecuritizing the impact of kin-states, the HCNM must strike a balance between the requirements of societal and institutional integration and the need to address legitimate self-governance demands.

\section{Conclusions and recommendations}

Using the Lund Recommendations and other international standards as a framework of analysis, this piece has sought to highlight selected areas of minority political participation where there is acute awareness of the need to balance integration and separation concerns. While there is no standard definition of "effectiveness" in group involvement, or indeed any generally agreed parameters around this notion in international legal terms, follow-up work by the HCNM in this area would be highly desirable, at least from a conflict prevention perspective. By way of conclusion, the following list identifies areas of possible future HCNM action, with a focus on the Lund Recommendations: 
1) Political parties. While the HCNM has broadly recognized both mainstream parties and minority parties as legitimate channels of political participation for national minorities, the Lund Recommendations do not provide clear guidance on incorporating minority concerns into mainstream parties in a way that meets the test of effective participation. Specific parameters that spell out the practical implications of minority involvement in mainstream parties could be developed in this area, including guarantees against the co-optation of individual minority leaders and the dilution of collective minority political participation.

2) Special measures. The impact of certain special measures on minority integration in the electoral process should be treated by the HCNM with a healthy dose of policy realism. In the absence of clearly better and widely shared policies supported by the group, the focus should be on finetuning and perfecting such measures in areas such as candidate nomination for minority lists, the level of minority voter choice, and minority voter registration systems (in coordination with ODIHR). This is another area where the Lund Recommendations could be further developed by elaborating on the distinction between complex forms of minority protection and general anti-discrimination measures.

3) Consultative bodies. Although the composition and functioning of consultative bodies established by nation- al legislation or in response to multilateral or bilateral standards (mainly bilateral treaties in cross-border regions) are arguably at the centre of any credible "integration with diversity" approach to minority issues by the state, the scope of the Lund Recommendations in this area remains limited. One area that requires special attention is pluralism, both within groups and in relation to minority participation in society more generally. This importantly includes (but should not be limited to) gender issues. Rather than being left to general freedom of association standards, it should involve inclusive conversations on the detailed national policies that OSCE participating States can adopt to secure minority pluralism and on how the Lund Recommendations can help to expand our understanding of the concept (including its ramifications) and to measure its impact on national policies.

4) Self-governance. While hardly any new territorial autonomy arrangements have been made in the OSCE geographical region since the Lund Recommendations were adopted in 1999 and no right to autonomy has emerged (or is likely to emerge) in international law more generally, modalities of self-governance are bound to remain at the forefront of the HCNM/OSCE policy agenda, particularly in the context of OSCE cross-border regions. As the case of Ukraine's Hungarian minority illustrates, the multidimensional link between self-governance claims, integra- 
tion, and de-securitization requires proper elaboration and articulation if the Lund Recommendations are to play a significant role in such scenarios (in conjunction with the Ljubljana Guidelines on integration and the Bolzano Recommendations on kin-states). A holistic approach to selfgovernance should articulate, at the level of HCNM standards, a more coherent synthesis of these issues as a basis for advisory services at the country level.

Following a well-established working pattern, the HCNM could convene and sponsor expert meetings tasked with initiating the formal revision and expansion of the Lund Recommendations in the above-mentioned areas, drafting a consolidated version of the relevant set of HCNM recommendations, and carrying out targeted follow-up activities. Rather than evaluating the pros and cons of these options, this paper has sought to identify key areas of minority political participation in which the friendly advisory assistance offered by the HCNM must strike a balance between integration and separation demands. No matter which path is pursued, it is clear that any such initiative must receive the active input and support of OSCE participating States, which remains a precondition for productive HCNM engagement.

\section{Notes}

For the details of the HCNM's mandate and related resources, see "Mandate", OSCE, https://www.osce.org/hcnm/1078
78. See, generally, John Packer, "Making International Law Matter in Preventing Ethnic Conflict: A Practitioner's Perspective", in: New York University Journal of International Law and Politics 3/2000, 715-724.

2 Virtually all High Commissioners have embraced this narrative over the past nearly thirty years: see for example Max van der Stoel, Speech by Max van der Stoel, High Commissioner on National Minorities at a Seminar, Prague, 13 May 1994, http://www.osce.org/hcnm/3725 9; Max van der Stoel, Early Warning and Early Action: Preventing Inter-Ethnic Conflict, 9 July 1999, http://www.os ce.org/hcnm/32107; Lamberto Zannier, Keynote Speech by Lamberto Zannier to the United Nations Forum on Minority Issues, 27 November 2019, https://www.o sce.org $/ \mathrm{hcnm} / 440084$

3 Lamberto Zannier was particularly vocal on this front. See (inter alia) his UN speech (cited above, Note 2); for broader analyses, see also Iryna Ulasiuk/Laurențiu Hadîrcă/William Romans (eds), Language Policy and Conflict Prevention, Leiden and Boston: Brill/Nijhoff, 2018.

E.g. UNESCO, Convention Against Discrimination in Education, 14 December 1960, Article 5(1)(c), http://portal.unesc o.org/en/ev.php-URL_ID=12949\&URL DO=DO_TOPIC\&URL_SECTION $=20$ 1.html; OSCE, Document of the Copenhagen Meeting of the Conference on the Human Dimension of the OSCE, 29 June 1990, para. 34, https://www.osce.org /odihr/elections/14304; COE, Framework Convention for the Protection of National Minorities and Explanatory Report, H(95)10, February 1995, Article 14(3), https://rm.coe.int/16800c10cf. See generally, Gaetano Pentassuglia, Minorities in International Law, Strasbourg: Council of Europe Publishing/ECMI, 2002.

OSCE, The Lund Recommendations on the Effective Participation of National 
Minorities in Public Life, 1 September 1999, https://www.osce.org/hcnm/lund-r ecommendations

Marc Weller (ed.), Political Participation of Minorities: A Commentary on International Standards and Practice, Oxford: Oxford University Press, 2010. See more recently, inter alia, Markku Suksi, "Effective Participation of Minorities in Public Affairs and Public Life: European Norms and Praxis Evaluated in Light of the Lund Recommendations", in: Vizi Balázs/Toth Norbert/Edgár Dobos, Beyond International Conditionality: Local Variations of Minority Representation in Central and South-Eastern Europe, Baden-Baden: Nomos, 2017, 11-49; William Romans, Iryna Ulasiuk and Anton Petrenko Thomsen (eds.), Effective Participation of National Minorities and Conflict Prevention (Leiden and Boston: Brill/Nijhoff, 2020).

COE, Advisory Committee on the Framework Convention for the Protection of National Minorities, Commentary on the Effective Participation of Persons Belonging to National Minorities in Cultural, Social and Economic Life and in Public Affairs, ACFC/31DOC(2008)001, 27 February 2008, https:/ /rm.coe.int/CoERMPublicCommonSearc hServices/DisplayDCTMContent?docum entId $=09000016800 \mathrm{bc} 7 \mathrm{e} 8$

UNHR, International Covenant on Civil and Political Rights, 16 December 1966, https://www.ohchr.org/en/professionalin terest/pages/ccpr.aspx

9 OSCE, cited above (Note 5), Sec. B, 8.

10 COE, cited above (Note 7), para. 78.

11 See the 2001 Office for Democratic Institutions and Human Rights Guidelines, https://www.osce.org/odihr/elections/1 7569 and the 2002 Venice Commission Guidelines, https://www.venice.coe.int/w ebforms/documents/?pdf=CDL-AD(2002 )023rev2-cor-e

COE, cited above (Note 7), para. 78.
13 Dmitry Nurumov/Vasil Vashchanka, "Effective Participation of National Minorities in the Electoral Process", in: William Romans/Iryna Ulasiuk/Anton Petrenko Thomsen (eds.) cited above (Note 6), 197-211.

14 OSCE, cited above (Note 5), Sec. II, A.

15 A key HCNM senior legal adviser at the time noted that for the High Commissioner, the arrangement "seemed to constitute a useful means of supporting effective participation of minorities and their integration". See Krzysztof Drzewicki, "OSCE Lund Recommendations in the Practice of the High Commissioner on National Minorities", in: Marc Weller (ed.), cited above (Note 6), p. 274.

16 United Nations General Assembly, Report of the Committee on the Elimination of Racial Discrimination, Seventyfifth session, General Recommendation 32, Annex VIII, 3-28 August 2009, https:/ /undocs.org/en/A/64/18

17 This is arguably supported, directly or indirectly, by elements of the Framework Convention and the European Court of Human Rights itself. See Suksi, cited above (Note 6), pp. 31, 33-34.

18 William Romans/Iryna Ulasiuk/Anton Petrenko Thomsen (eds.), cited above (Note 6), pp. 210-211.

OSCE, cited above (Note 5), Sec. II, D, 12.

20 E.g., Grosaru v. Romania, Appl. No. 78039/01, European Court of Human Rights, Judgment of 2 March 2010; Ofensiva Tinerilor $v$. Romania, Appl. No. $16732 / 05$, European Court of Human Rights, Judgment of 15 December 2015.

21 Gaetano Pentassuglia, Minority Groups and Judicial Discourse in International Law, Leiden and Boston: Brill/Nijhoff, 2009, pp. 142-147.

22 Anton Petrenko Thomsen, "Taking the Lund Recommendations One Step Forward: Introducing a Measurement Ap- 
proach", in: William Romans/Iryna Ulasiuk/Anton Petrenko Thomsen (eds.), cited above (Note 6), 230-252.

23 OSCE, cited above (Note 5), Sec. III.

24 Lamberto Zannier, Address by Lamberto Zannier OSCE High Commissioner on National Minorities to the 1270th Plenary meeting of the OSCE Permanent Council, HCNM.GAL/3/20/Rev.2, 4 June 2020, p. 3, https://www.osce.org/files/f/d ocuments/1/1/453807.pdf

25 OSCE, The Ljubljana Guidelines on Integration of Diverse Societies, 7 November 2012, https://www.osce.org/hcnm/ljublja na-guidelines; OSCE, The Bolzano/Bozen Recommendations on National Minorities in Inter-State Relations, 2 October 2008, https://www.osce.org/hcnm/bolzan o-bozen-recommendations
26 OSCE, Ljubljana Guidelines, cited above (Note 25), p. 17.

27 David Smith and Mariana Semenyshyn, "Addressing Hungarian Minority SelfGovernance Claims in Zakarpattya: An Assessment in Light of the Lund Recommendations", in: William Romans/Iryna Ulasiuk/Anton Petrenko Thomsen (eds.) cited above (Note 6), 123-143.

28 Kairat Abdrakhmanov, Address by Kairat Abdrakhmanov OSCE High Commissioner on National Minorities to the 1318th Plenary meeting of the OSCE Permanent Council, HCNM.GAL/3/21/ Rev.1, 3 June 2021, pp. 10-11, https://w ww.osce.org/files/f/documents/a/4/48976 7_0.pdf 
